Teoretická studie

\title{
COMPUTER THERAPY AS CONCEPT OF NEW FORM OF THERAPY FOR ITELLECTUAL DISABLED PEOPLE: THEORY AND PRACTISE
}

\section{Jiři KRAJÍČEK - Radek KOČÍ}

Abstract: In this paper we present study and current state of research - the design and creation of new therapy for intellectual disabled people, called computer therapy. The goal is to apply resources of IT properly in synthesis with methods of special education, social care and informatics (informatics education), to create unified concept of therapy, which is easily accessible, long termed, applicable in natural environment of people with intellectual disability. Thus we finally compensate or decrease the impact of intellectual disability in lives of these people. To do so, we come from unsatisfactory state of last years following the success of touch devices achieved in special pedagogy. Hence this therapy demands to cover this issues in whole life cycle, starting from mostly informatics area - the development of specific application through its deployment on suitable device to use it practise by intellectual disabled people by covering their individual, specific needs. In this application phase of computer therapy life cycle, there is more contribution from area of special education and social care. Such unified process is presented in designed concept of computer therapy, which is subsequently verified.

Keywords: computer therapy, intellectual disability, special education needs, touch device, intellectual progress 


\section{POČÍTAČOVÁ TERAPIE JAKO KONCEPT NOVÉ FORMY TERAPIE PRO OSOBY S MENTÁLNÍM POSTIŽENÍM: TEORIE I PRAXE}

Resumé: V tomto článku prezentujeme studii a aktuální stav výzkumu realizace nové terapie pro osoby s mentálním postižením označované jako „počítačová terapie“. Cílem je vhodně aplikovat prostředky informačních technologií při syntéze metod ze speciální pedagogiky, sociálních služeb a informatiky (informatické výchovy), aby mohl vzniknout jednotný koncept terapie, která je snadno dostupná, má dlouhodobý charakter, je použitelná $\mathrm{v}$ přirozeném prostředí osob $\mathrm{s}$ mentálním postižením, tak že v konečném cíli kompenzujeme nebo snižujeme dopad mentálního postižení v běžném životě těchto osob. Vycházíme při tom z neuspokojivého stavu řady předešlých let a navazujeme na již dosažený úspěch aplikace dotykových zařízení zejména ve speciální pedagogice, který je nazýván revolucí speciální pedagogiky. To vyžaduje uchopení této problematiky v celém jejím životním cyklu, od počátku, převážně informatické oblasti - od vývoje potřebných aplikací přes jejich nasazení na IT zařízení až po další využívání k realizaci, aplikaci na individuální cíle osob, kde je pak více vkladu z oblasti sociálních služeb a speciální pedagogiky. A právě o takto unifikovaný přístup usilujeme v navrženém konceptu ,počítačové terapie“, který je postupně ověřován.

Klíčová slova: počítačová terapie, mentální postižení, specifické poruchy učení, dotykové zařízení, rozvoj rozumových schopností 


\section{1 Úvod}

$\mathrm{V}$ předešlých letech jsme mohli sledovat rozvoj nástrojů a metod z oblasti informačních technologií (dále IT) pro vzdělávání a rozvoj osob s mentálním postižením [6]. Docházelo tak $\mathrm{k}$ utváření velmi specifických technických prostředků a spjatých metod, např. pomocí tlačítek, komunikátorů či specificky upravených PC s aplikacemi, které byly často graficky zastaralé a cenově obtížně dostupné. Nevýhodou těchto zařízení zůstávala jejich vyšší pořizovací cena s ohledem na jejich specifičnost, jednoúčelovost a obtížná modifikovatelnost. $\mathrm{Z}$ toho pak plynou i omezení pro možnou práci s těmito zařízeními pro potřeby interaktivního vzdělávání a rozvoje osob s mentálním postižením.

Hledáme-li efektivní řešení pro rozvoj osob s mentálním postižením, musíme se zabývat otázkami snadné dostupnosti, rozšiřitelnost, kompatibility, ale také úpravou dle individuálních potřeb osob, tedy zda aplikace $\mathrm{v}$ dané platformě je použitelná i pro vzdělávání a rozvoj osob i v mimoškolním vzdělávání v každodenních potřebách. Tyto otázky jsou tak propojením několika oblastí - problematiky speciální pedagogiky, sociálních služeb a informačních technologií resp. informační výchovy. V tomto článku chceme představit koncept terapie označovaný jako počítačová terapie, která usiluje o prrirozené vypořádávání s těmito problematic- kými otázkami. Tento koncept může být dále využit jako podklad $\mathrm{k}$ vytvoření komplexní metodiky pro využití zejména dotykových zařízení $\mathrm{u}$ osob $\mathrm{s}$ omezenými schopnostmi intelektu.

Koncept počítačové terapie je dílem odborných pracovníků z ústavu sociální péče Křrižanov (ÚSP KřiŽanov) ve spolupráci s dalšími subjekty zejména s Fakultou informačních technologií Vysokého učení technického v Brně (VUT FIT). Obsahem této terapie je rozvoj osob s mentálním postižením v několika základních oblastech s ohledem na jejich individuální potřeby. Důraz je kladen zejména na dlouhodobý rozvoj v prostředí, kde osoba přirozeně žije. Terapie je zde nejprve představena jako hypotéza (teoretický koncept), která stanovuje požadovaná kriteria na základě analýzy současného stavu. Hypotéza je ověřována prováděnou studií a také na základě několikaletých zkušeností komunity iSEN (komunita odborných pracovníků sdílející informace o využití IT zařízení k rozvoji dětí a žáků se specifickými potřebami) a dalších odborných publikací. Nakonec jsou na základě této práce vyvozeny závěry - potvrzení konceptu a započat návrh i vývoj aplikací splňujících potřebná kritéria.

\section{Definice}

Název je odvozen z termínu „computer therapy“ nebo ,e-thera- 
py“, který zpravidla vyjadřuje obecně rozvoj člověka prostřednictvím prostředků IT. Zde je tento pojem redefinován, $v$ našem prrípadě počítačovou terapií konkrétně rozumíme využití dostupného potenciálu IT nástrojů a metod k rozvoji rozumových schopností osob s mentálním postižením a kombinovanými vadami (lehké a středně těžké mentální postižení) ve smyslu kompenzace, reedukaci (posílení schopnosti, nahrazení nedostatečnosti vlivem postižení). Přirozeně se zde využívají také odborné a osvědčené metody $\mathrm{z}$ pedagogiky a speciální pedagogiky.

\section{Východiska počítačové terapie}

V úvodu jsme poukázali na neudržitelný stav předešlého vývoje. Avšak s rozvojem přenosných zařízení nejprve na platformě Apple (tablety iPad) v roce 2010 se v zápětí objevila i snaha využít tato zařízení pro potřeby osob s mentálním postižením - zejména ve speciální pedagogice $[2,5]$. Následně $v$ roce 2011 vznikla na této platformě v ČR neformální komunita iSEN (Speciální základní škola Poděbrady). Dochází tak k utváření nové metodiky pro vzdělávání a kurzů pro školení (akreditováno MŠMT) - [7]. Toto rozšíŕení ovlivnilo také oblast základního a středoškolského vzdělání a nastolilo nové otázky a možnosti pedagogiky v praxi. Právem je pak začlenění tabletů do výuky na speciálních školách nazýváno revolucí ve speciální pedagogice [8].

Obecně lze říci, že s příchodem konceptu, zcela odlišného od využívání osobních počítačů, se řada možností IT stala pro osoby s mentálním postižením přirozeně dostupná. Tento zlom způsobil rychlý nárůst vývoje aplikací pro dotyková zařízení a tak $\mathrm{v}$ důsledku vzniká i řada volně dostupných aplikací s využitím pro vzdělání a rozvoj osob s mentálním postižením. V současné době je nejvíce dostupných vhodných aplikací na platformě Apple (iPad, iPhone). S rozšířením tabletů a chytrých telefonů s operačními systémy (OS) Android a OS Windows 8 lze $\mathrm{v}$ následných letech očekávat nárůst vývoje i na těchto platformách.

Východiskem počítačové terapie je zmíněná koncepce metod speciálního vzdělávání představovaná komunitou iSEN. Kromě toho však chceme vytvářet otevřené prostř̌edí, abychom umožnili rozvoj většině osob s mentálním postižením v jejich sociální oblasti a nabídli další vhodné technické prostředky.

\section{Přínos počítačové terapie}

Snahou počítačové terapie je podpora otevřeného prostředí nejen v technickém slova smyslu. Proto se počítačová terapie nezaměřuje jen na prostředí speciální základní školy, ale převádí tyto metody do prostředí běžného života osob s mentálním postižením. Můžeme 
napřr. poukázat na osoby, které dříve do speciální školy docházely a nyní již tuto možnost nemají nebo neměly. Také vnímáme nezbytný aspekt kontinuity - pokud je narušen, získané kompetence jsou často zapomenuty. Počítačová terapie je proto navržena jako stálá aktivita, která je osobám s mentálním postižením nabízena pravidelně dle jejich individuálního plánu.

Počítačová terapie se nedotýká jen vlastní oblasti vzdělávání, resp. reedukace (mimoškolní vzdělávání), ale zasahuje i oblasti prridružené a tak je $\mathrm{v}$ propojení $\mathrm{s}$ dalšími dostupnými terapiemi. V širším měřítku pak počítačová terapie zahrnuje následující oblasti:

- $\quad$ specifické vzdělávání, které je odpovědí na speciální vzdělávací potřeby (special eddational needs - SEN) - IT zařízení plní funkci vzdělávací pomůcky (např. výuka čtení, psaní, matematika),

- asistenční technologie (odpovídá termínu ,assistive technology“, [5]), tj. zařízení plnící funkci kompenzační pomůcky, např. pro potřeby alternativní komunikace (AAK), stává se príidruženou částí osoby,

- rozvoj rozumových schopností obecně, zejména s cílem zvládat praktické potřeby denního života,

- volnočasové aktivity, napřr. forma relaxace, odpočinku a

- propojení $s$ jinými mimoškolními terapiemi, např. $s$ arteterapií, muzikoterapií, hmatovou terapií, fyzioterapií.

Jak bylo naznačeno ve východiscích počítačové terapie, neopomíjíme ani alternativní platformy používané na dotykových zařízeních, - jedná se zejména o tablety a chytré telefony s OS Android a OS Windows 8. Proto také usilujeme o odstínění platformových odlišností umožňující zachovat vzhled a způsob ovládání aplikace, která je dostupná pro různé platformy, např. tablet s OS Android nebo iPad. Tento aspekt považujeme za zásadní, nebot' osoby s mentálním postižením mohou mít aplikaci $\mathrm{k}$ dispozici na různých dotykových zařízeních na odlišných platformách.

Počítačová terapie počítá i s oblastí obecné informatické gramotnosti a je proto otevřena i práci s klasickým osobním počítačem. Využití osobních počítačů je však vhodné zejména pro osoby s lehkým mentálním postižením, kde nejsou zpravidla obtíže při interakci prostřednictvím běžné klávesnice nebo myši. 
V důsledku tak dochází k syntéze rozličných technických prostředků (od klasických osobních počítačů až po dotyková zařízení) a metod především speciální pedagogiky $\mathrm{k}$ řešení společného cíle dlouhodobého rozvoje osob s mentálním postižením $\mathrm{v}$ jejich přirozeném prostředí $\mathrm{k}$ lepšímu, samostatnějšímu zvládání základních životních potřeb. To je podstatné i s ohledem na probíhající transformaci v sociálních službách. Usilujeme tak, aby metody počítačové terapie podporovaly otevřená řešení jak po stránce technické, tak i po stránce potřeb osobního rozvoje i v ostatních sociálních prostředích.

\section{Hypotéza a fundament počíta- čové terapie}

V této části chceme vystihnout a formulovat podstatu počítačové terapie jako komplexního konceptu pro efektivní rozvoj osob s mentálním postižením. Tento fundament byl nejprve formulován jako hypotéza a následně je potvrzován na základě závěrů ověřovací studie (viz níže realizace počítačové terapie) a zkušeností neformální komunity iSEN, která se zaměruje převážně na praktické využití tabletů iPad ve speciální pedagogice.

\section{Hypotéza:}

„Při syntéze současných požadavků a prostředků IT, speciální pedagogiky a sociálních služeb (dle kritérií konceptu počítačové tera- pie, viz níze) je rozvoj osob s mentálním postižením efektivnější, dlouhodobě udržitelný a vede $k$ větši samostatnosti těchto osob v jejich přirozeném prostředí.“

Kritéria konceptu z pohledu informatiky (zejména s ohledem na dostupnost, rozšiřitelnost a kompatibilitu):

- podpora pro různé otevřené platformy s cílem zajistit dostupnost na většině nejrozšîřenějších dotykových zařízeních s různými operačnímy systémy, např. iOS, Android nebo Windows 8 ,

- prostředí pro tvorbu sady programů a aplikací splňujících požadavky pro celkový rozvoj osob s mentálním postižením, jak je uvedeno $v$ kapitole Př́nos,

- volná dostupnost aplikací pod vhodnou otevřenou licencí, která dovoluje užití aplikací a jejich další vývoj širokou komunitou,

- dodržení standardů a obvyklých požadavků na tvorbu softwarových produktů, jako je objektově orientovaný návrh, dostupnost dokumentace, apod.

Kritéria konceptu z pohledu speciální pedagogiky a sociálních služeb: 
- aplikace musí reflektovat reálné a podstatné potřeby osoby $\mathrm{s}$ mentálním postižením (např. alternativní komunikace),

- aplikace musí být použitelná v prostředí speciální pedagogiky i mimoškolního vzdělávání a volnočasových aktivit (viz přehled v kapitole Přínos), tedy prostředí, kde osoba s mentálním postižením přirozeně žije,

- využití aplikace na dané platformě by mělo umožnit spolupráci s individuálním plánováním osoby s mentálním postižením, tedy s ohledem na její další aktivity a zájmy,

- aplikace musí podporovat dlouhodobý rozvoj osoby s mentálním postižením, a to i v mimoškolním prostředí (napřs. rodina, sociální zařízení), tedy $\mathrm{v}$ prírozené prostředí,

- grafické uživatelské rozhraní musí být intuitivní a snadno ovladatelné s využitím běžných dotyků, podporovaných v dotykovém zařízení,

- aplikace musí obsahovat uživatelský režim (pro osobu s mentální postižením) a režim správce, který dovoluje přidání či změnu obsahu dle indi- viduálních potřeb osob s mentálním postižením, případně nastavení omezení běhu aplikace, tak aby nedocházelo k utváření nezdravé závislosti nebo nevhodného zásahu, který by mohl ovlivnit bezpečnost a zdraví osoby $\mathrm{s}$ mentálním postižením.

\section{Ověřování: realizace počítačové terapie}

Počítačová terapie je za podpory vedoucích pracovníků postupně realizována $v$ prostředí ÚSP Křižanov (poskytovatel služeb chráněného bydlení a domov pro osoby se zdravotním postižením) a Fakulty Informačních Technologií VUT v Brně od konce roku 2012. Níže uvedená kazuistika (březen 2013 srpen 2013) je pouze první hrubým podkladem $\mathrm{v}$ tomto dlouhodobém projektu a nenahrazuje komplexní statistiku pro verifikaci zmíněné hypotézy. Ta bude následovat v průběhu dlouhodobějších a podrobnějších studií, které jsou nyní připravovány.

Celá realizace formování konceptu počítačové terapie zahrnuje dvě etapy. První etapou je ověření využití stávajícího volně dostupného softwaru a hardwaru pro počítačovou terapii. Druhá zahrnuje reflexi $\mathrm{z}$ této studie, tj. ověřování hypotézy počítačové terapie, případně její upřesnění, a na jejím základě pak návrh a vývoj nových aplikací splňujících požadavky 
uvedené v kapitole 4 - Fundament počítačové terapie.

Nejprve uvedeme z první etapy stručnou kazuistiku. V současné době probíhá transformace ÚSP Křižanov, jejímž cílem je snaha o začlenění osob s mentálním postižením do prostředí běžného života. V první etapě realizace počítačové terapie, která proběhla $\mathrm{v}$ rámci uvedené transformace, se terapie zúčastnili i klienti, kteří jsou začleněni do běžného života $\mathrm{v}$ domku nebo bytech (poskytovaná služba chráněné bydlení).

Realizace probíhala se skupinou 26 klientů s různými stupni mentálního postižení (10 klientů s lehkým a 16 klientů se středním postižením), se specifickými poruchami učení (SPU) a poruchami soustředěnosti (ADD a ADHD). Pro realizaci byla zvolena dotyková zařízení a klasický osobní počítač. Z dotykových zařízení byly použity tablety Apple iPad (operační systém iOS), Lenovo PC IdeaCenter (operační systém Windows 8) a chytrý telefon s operačním systémem Android ICS. Dále byla použita platforma běžného stolního PC s operačním systémem Windows XP. Cílem bylo nejprve ověrit volbu vhodné platformy $\mathrm{s}$ ohledem na oblasti postižení a individuální potřeby osoby s mentálním postižením, dále míru získání schopnosti osoby obsluhovat zařízení a posléze rozvoj osoby $\mathrm{v}$ jeho primární potřebě prostřednictvím $\mathrm{k}$ tomu vybra- ných aplikací. Následující výčet shrnuje pozorované výsledky první etapy:

$\begin{array}{llllll}8 & \mathrm{z} & 10 & \text { klientů } & \mathrm{s} & \text { lehkým }\end{array}$ mentálním postižením zvládlo základní obsluhu na klasickém osobním počítači, jako cíl bylo zvoleno zvýšení jejich informatické gramotnosti. Klienti byli seznámeni se základy koncepce osobního počítače, stavby hardwaru a odlišností softwaru podle účelu. Následně zvládli základní práci v OS Windows a práci $\mathrm{v}$ textovém procesoru; klienti byli schopni samostatně napsat e-mail a jednoduchý textový dokument, např. dopis nebo svůj příběh.

2 z 10 klientů s lehkým mentálním postižením činila práce $\mathrm{s}$ osobním počítačem potíže zejména $\mathrm{z}$ důvodu neporozumění znakům, klávesnice (převážně alfanumerickým znakům) a obtížné ovladatelnosti tlačítek myši. U těchto klientů se ukázala jako prioritní potřeba rozvoje čtení, psaní a počítání. Abychom porovnali možnosti využití dotykové platformy operačního systému Android s platformou operačního systému Apple - iOS, byla pro první seznámení (ovládání OS, spuštění aplikací, navigace mezi aplika- 
cemi) nejprve zvolena platforma chytrého telefonu s OS Android a posléze se podařil bezproblémový přechod na platformu s iOS iPad. Zde následně proběhlo využití metody globálního čtení zejména $\mathrm{v}$ aplikaci BitsBoard. V součinnosti této analytické metody čtení ve spojení s dotykovou platformou se klienti učili číst, porozumět novým slovům a zpětně i jejich znakům. Pro srovnání, před realizací počítačové terapie nebyla u těchto osob schopnost rozlišit správně písmena abecedy a byla dovednost číst např. jen 2 známá slova.

- 10 z 16 klientů se středním mentálním postižením činila práce $\mathrm{s}$ osobním počítačem potíže (ze stejných důvodů jako je popsáno u předešlé skupiny) a proto využilo platformu tabletu iPad s následujícími cíli dle svých potřeb:

○ $\quad 3 \quad$ z 10 klientů využili aplikace pro rozvoj čtení, psaní a počítání s obdobnými výsledky jako klienti s lehkým mentálním postižením.

○ $\quad \begin{array}{llll}\mathrm{z} & 10 & \text { klientů využili }\end{array}$ aplikace pro alternativní a augmentativní komunikaci (AAK). Klienti zvládli porozumět sadě piktogramů, dovedli formulovat jednoduché věty prostřednictvím AAK aplikací s českým hlasovým syntetizátorem. Klienti se tak i přes postižení $\mathrm{v}$ řeči učí komunikovat se svým okolím. Zvládnou prostřednictvím aplikace s dopomocí vyjádřit jednoduché věty, jako své prrání, zážitky, události. Práce zejména $\mathrm{v}$ české aplikaci Klábosil.

○ $\quad 3 \quad$ z 10 klientů využili aplikace pro uměleckou tvorbu a všeobecný rozvoj. Tito klienti měli problémy $\mathrm{s}$ řešením jednoduchých úloh, zejména problémy s pozorností a soustředěním. Pomocí zjednodušené simulace arteterapie, tvorby keramiky, hry na strunné hudební nástroje (tzv. finger style) a náslechů zvuků $\mathrm{z}$ běžného života, dokázali řešit praktické úkoly $\mathrm{z}$ těchto oblastí, což nebylo do této doby možné.

- 6 z 10 klientů se středním mentálním postižením činila opět práce $\mathrm{s}$ osobním počítačem potíže, a proto využili také dotykovou platformu. Avšak s ohledem na jejich věk 
(senioři) a obtížnost jemné motoriky byla zvolena platforma dotykového PC - Lenovo IdeaCenter (k dispozici také v rámci multismyslové terapie). Tato platforma disponuje větší dotykovou plochou (23" oproti 10" platformy iPadu). Pomocí zde dostupných aplikací byl realizován cíl v trénování paměti, řešení logických úloh (úlohy reminiscenční terapie) a relaxace. Větší plocha se ukázala jako vhodná pro potřeby relaxační projekce a pro řešení obtíží s jemnou motorikou.

Z uvedené kazuistiky vyplývá několik závěrů, které rámcově potvrzují některá tvrzení hypotézy konceptu počítačové terapie:

- potvrzení závěrů jiných odborných publikací [1, 3, 4], které uvádějí, že využití prostředků IT, zejména dotykových zařízení, představuje prrínos $\mathrm{v}$ rozvoji osob $\mathrm{s}$ mentálním postižením,

- potvzení doporučení ze závěrů odborných studií např. [8, 9], tedy potřeby nabídnout osobám $\mathrm{s}$ inteligenčním deficitem rozvoj pomocí IT prrímo $\mathrm{v}$ jejich vlastním prostř̌edí (mimoškolní vzdělávání, terapie, aktivizace).
- je vhodné osobám s mentálním postižením nabídnout různá dotyková zařízení, odlišná např. velikostí, tvarem provedení, ale i cenovou dostupností,

- potřeba přenosu vhodné aplikace na jinou platformu, kde není aplikace standardně podporována (viz např. aplikace z oblasti muzikoterapie - ,TinyPiano“),

- potřeba rozšíření stávajících aplikací - podpora rodného jazyka osoby $\mathrm{s}$ mentálním postižením, úprava funkcionality, přidání nových položek apod.,

- potřeba volné dostupnosti aplikace zejména s ohledem na neziskový sektor, ve kterém osoba s mentálním postižením zpravidla žije.

Druhá etapa realizace počítačové terapie je reakcí na některé dostupné závěry. $\mathrm{Na}$ jejich základě, i s ohledem na zkušenosti a podměty z komunity iSEN, byly již navrženy tři aplikace, které jsou ve spolupráci s ÚSP Křižanov realizovány na VUT FIT týmem studentů v rámci bakalářských a diplomových prací. Jedná se zatím o tři následující aplikace: 
- Aplikace pro alternativní a augmentativní komunikaci pro osoby s mentálním postižením

- Aplikace pro výuku znaku do řeči pro osoby $\mathrm{s}$ mentálním postižením

- Aplikace pro YES/NO alternativní komunikaci pro osoby s mentálním postižením

Dokončení vývoje aplikací s jejich uvolněním je očekáváno ke konci akademického roku 2013/ 2014. Aplikace by měly splňovat požadavky konceptu počítačové terapie a $\mathrm{s}$ probíhajícími studiemi budou vhodně upravovány. S ohledem na otevřenost zdrojových kódů je otevřena cesta i pro budoucí potřebný vývoj. V prř́štím akademickém roce chceme pokračovat rozšířením sady o další aplikace, které budou nápomocné $\mathrm{k}$ rozvoji podstatných aspektů počítačové terapie, jež jsou zmiňovány v kapitole 3 - Přínos počítačové terapie.

\section{Závěr}

V tomto článku jsme prezentovali koncept rozvoje osob s mentálním postižením prostřednictvím současných prostředků IT nazvaný počítačová terapie. Přestože v ČR (neformální komunita iSEN) i v zahraničí již existují odborné metody i publikace [4], které poukazují na přínos dotykové platformy pro osoby s mentálním postiže- ním, byly tyto snahy zatím platformově izolované a pro technické odlišnosti nekompatibilní nebo ne zcela zahrnuté do přirozeného prostředí osob s mentálním postižením. Navíc, aplikace na dané platformě nejsou vždy volně dostupné nebo upravitelné, často nevyhovují potřebám metod speciální pedagogiky, což je pro individuální vzdělávání a rozvoj osob s mentálním postižením nezbytné. Proto jsme navrhli teoretický koncept počítačové terapie, který je následně ověřován. Pokud se naplní naše očekávání, může být tento koncept zásadním podkladem pro vznik metodiky počítačové terapie v obecném slova smyslu a prrispět tak ke standardizaci této terapie vedle již běžně dostupných terapií pro osoby s mentálním postižením. Na základě již potvrzených kritérií tohoto konceptu byl zahájen návrh a vývoj aplikací splňujících stanovená kritéria, která by měla ve výsledku prrispět $\mathrm{k}$ lepší dostupnosti a použitelnosti hardwarových i softwarových prostředků IT, zejména na dotykových platformách, pro osoby s mentálním postižením.

Během studie současných trendů nám nebyla známa obdoba tohoto konceptu, která by takto reflektovala individuální potřeby $\mathrm{v}$ prrirozeném prostředí osob $\mathrm{s}$ mentálním postižením při využití syntézy hardwarových i softwarových prostředků IT. Proto jsme také prezentovali jednoduchou prípadovou 
studii, abychom již nyní poukázali na reálné možnosti a př́inos počítačové terapie $\mathrm{v}$ praxi, a to i tam, kde již není možný kontakt osoby s mentálním postižením s prostředím speciální školy.

\section{Diskuse}

Vzhledem k nekonvenčnímu přístupu prezentované počítačové terapie mohou v odborné komunitě vyvstat některé otázky. Abychom předešli některým nejasnostem, uvádíme na závěr krátkou spekulaci možných tvrzení $\mathrm{k}$ otázce prŕístupu počítačové terapie.

Tato problematika je ř řsena již v rámci docházky do speciálních, praktických škol nebo v rámci integrace do Ž̌ nebo SŠ.

Počítačové terapie je mezioborovým tématem, kde je nezbytný vklad, spolupráce jak z řad speciálních pedagogů, pracovníků sociálních služeb a právě i informatiků (pedagogů informatiky). Tato mezioborovost je přirozeným důsledkem řešené problematiky, která je v neuspokojivém stavu.

Některé prostředky IT zařízení (tablety iPad) jsou sice používány v rámci speciální pedagogiky v rámci možné docházky na některých speciálních školách (v ČR zejména díky komunitě iSEN), ovšem řada osob s mentálním postižením tuto možnost už nemá, nebo neměla. Převážná část denního času je žita $\mathrm{v}$ přirozeném pro- středí této osoby - tzv. sociálním prostředí. Proto se ukazuje jako nezbytné, nabídnout tato IT zařízení také $\mathrm{v}$ prostředí sociálních služeb, což vyžaduje odlišný př́ístup právě s ohledem na dlouhodobost a odlišnost ostatních podmínek.

Dále integrovanost osob $\mathrm{s}$ mentálním postižením $\mathrm{v}$ rámci školní docházky (a to i ZŠ či SŠ pokud je možná) nezohledňuje zcela potřeby těchto osob v jejich běžném životě ani nezbytné kritérium kontinuity. Proto poukazujeme na možnosti tohoto konceptu pracovat $\mathrm{v}$ přirozeném sociálním prostředí těchto osob i za hranicemi škol.

Problematiku využití nových technologii lze rešit aplikací většího dưrazu na již dostupnou informatickou výchovu.

Samotnou informatickou gramotnost u osob s mentálním postižením, je-li oddělena od problematiky speciální pedagogiky a sociálních služeb (tedy reálných, individuálních potřeb těchto osob v běžném začlenění), která navíc postrádá dlouhodobé kritérium kontinuity, považujeme za ne zcela dostatečnou a ne zcela efektivní.

$V$ čem spočivá prínos pro informatickou výchovu, pedagogy informatiky?

V okamžiku, kdy se IT zařízení (nyní napřr. tablet iPad) stává ústřední částí práce $\mathrm{i} \mathrm{v}$ samotné speciální pedagogice [7,8], přestá- 
vá být toto zařízení jen př́ležitostnou pomůckou a stává se ústředním bodem $\mathrm{v}$ práci $\mathrm{s}$ cílovou osobou i pro speciálního pedagoga. Toto je pak výzvou pro řady z informatiků, pedagogů informatiky, kde svými znalostmi a společně kolegy z řad speciálních pedagogů a pracovníků v sociálních službách (osob znalých i blízkých) navrhnou cílené metody pro řešení i běžných problémů osob s mentálním postižením. To vyžaduje uchopení této problematiky v rámci celého životního cyklu, tedy od počátku, převážně informatické oblasti - od specifičnosti vývoje potřebných aplikací přes jejich nasazení na IT zařízení až po metody využívání $\mathrm{v}$ potřebě osoby $\mathrm{k}$ realizaci individuálních cílů, kde je pak více vkladu z oblasti sociálních služeb a speciální pedagogiky.

Zmíněná spolupráce je naplňována i skrze otevřenou odbornou komunitu iSEN, zahrnující převážně speciální pedagogy, ale i informatiky a pracovníky sociálních služeb. Počítačová terapie je již přes 1 rok uskutečňována $\mathrm{v}$ prostředí, kde osoby s mentálním postižením dlouhodobě žijí. Z každého setkání jsou pořizovány pracovní výstupy, které budou použity pro další ověřování $\mathrm{v}$ nadcházejících připravovaných publikacích.

Počítačová terapie je tak přínosem i pro učitele informatiky, nebot' ukazuje na nové možnosti uplatnění svého vzdělání a zkuše- ností v rámci mezioborové problematiky.

\section{Poděkování}

Zde děkujeme Kraji Vysočina za poskytnutí finanční dotace $\mathrm{v}$ rámci našeho projektu „Aplikace tabletů iPad v počítačové terapii pro osoby s mentálním postižením“ (pořízení tabletů iPad) v rámci Fondu Vysočiny - grantového projektu ,Informační a komunikační technologie 2013“. Poděkování patří i vedení VUT FIT a všem zainteresovaným zaměstnancům a studentům za vstřícný prrístup, odbornou pomoc, otevřené prostředí pro akademickou spolupráci s ÚSP Křržanov, bez kterého by realizace tohoto konceptu nebyla možná. Dále poděkování patří i celému týmu komunity iSEN zejména speciálním pedagogům ze Speciální základní školy Poděbrady, jejichž dosavadní výsledky a úsilí zejména na poli aplikace dotykových tabletů iPad, jsou pro nás velkou motivací a inspirací.

\section{Literatura}

[1] BRADSHAW, J. The use of augmentative and alternative communication apps for the iPad, iPod and iPhone: an overview of recent developments. Inflow: Tizard Learning Disability Review, [online], 2013, Vol. 18 Iss: 1, s. 31-37 [cit. 2013-05-11]. ISSN: 13595474. 
Dostupné na

<http://dx.doi.org/10.1108/1359547 1311295996>

[2] HAGER, E. B. iPad Opens World to a Disabled Boy, In: New York Times, [online]. October 2010. [cit. 2013-05-11]

Dostupné na <http://www.nytimes.com/2010/10/ 31/nyregion/31owen.html?_r=0>

[3] ISASI, A. et al. Helping children with Intellectual Disability to understand healthy eating habits with an IPad based serious game, In: 18th International Conference on Computer Games: AI, Animation, Mobile, Interactive Multimedia, Educational \& Serious Games (CGAMES), [online], 2013, s. 169173 [cit. 2013-05-11]. ISSN: 9781-4799-0818-9

Dostupné na

$<$ http://dx.doi.org/10.1109/CGames .2013.6632628>

[4] JOWETT, E. L., et al. Using an iPad-based video modelling package to teach numeracy skills to a child with an autism spektrum disorder. Inflow: Informa Journal: Developmental Neurorehabilitation, [online], 2012, Vol. 15, s. 304312. [cit. 2013-05-11].

Dostupné na <http://dx.doi.org/10.3109/1751842 3.2012.682168>

[5] BAILEY, N., et al. Assistive Technology, Accommodations, and the Americans with Disabilities Act, Employment and Disability Institu- te Collection, [online studie]. 2011 [cit. 2013-05-11].

Dostupné na

<http://digitalcommons.ilr.cornell.e du/edicollect/1301/>

[6] TAM, et al. Evaluation of a Computer-Assisted, 2-D Virtual Reality System for Training People With Intellectual Disabilities on How to Shop, Inflow: Rehabilitation Psychology, [online], 2005, Vol 50(3), s. 285-291. [cit. 2013-05-11].

Dostupné na

<http://psycnet.apa.org/doi/10.1037 /0090-5550.50.3.285>

[7] ŘíHOVÁ, L. 2013. Možnosti využití ipadu ve speciálním vzdělávání. In: INSPO - Internet a informační systémy pro osoby se specifickými potřebami, brezen 2013, Kongresové centrum Praha, [online] Praha 2013. [cit. 2013-05-11]

Dostupné na

$<$ www.helpnet.cz/data/articles/dow n_71650.pdf>

[8] ŘÍHOVÁ, L. 2013. Tablet revoluce ve speciální pedagogice, In: Helpnet, [online] (C2013 [cit. 2013-05-11]

Dostupné na

<http://www.helpnet.cz/aktualne/76 483-3>

[9] UPTON D. at al., Evaluation of the impact of touch screen technology on people with dementia and their carers within care home settings, Commissioned by Department of Health West Midlands, Univeristy of Worcester, [online studie]. 2011 [cit. 2013-05-11]. 
Dostupné na

<http://79.170.44.96/lifestorynetwo

rk.org.uk/wp-content/uploads/

downloads/

2012/11/evaluation-of-the-impact-

of-the-use-of-touchscreen-

technology-with-people-with-

dementia-.pdf>

Ing. Jiř́i Krajíček

Ústav sociální péče Křížanov

jiri.krajicek@gmail.com

\section{Ing. Radek Kočí, Ph.D.}

Fakulta informačních technologií, Vysoké učení technické Brno

koci@fit.vutbr.cz 